This item was submitted to Loughborough's Research Repository by the author.

Items in Figshare are protected by copyright, with all rights reserved, unless otherwise indicated.

\title{
Implementing environmental improvements in a manufacturing context: a structured approach for the precast concrete industry
}

PLEASE CITE THE PUBLISHED VERSION

http://www.inderscience.com/search/index.php?action=record\&rec_id=17508

PUBLISHER

(C) Inderscience

VERSION

AM (Accepted Manuscript)

LICENCE

CC BY-NC-ND 4.0

\section{REPOSITORY RECORD}

Elhag, Hafiz K., Jacqueline Glass, Alistair G.F. Gibb, Martin A. Clarke, Clive Budge, and Geoffrey K. Bailey. 2019. "Implementing Environmental Improvements in a Manufacturing Context: A Structured Approach for the Precast Concrete Industry”. figshare. https://hdl.handle.net/2134/9036. 
This item was submitted to Loughborough's Institutional Repository (https://dspace.lboro.ac.uk/) by the author and is made available under the following Creative Commons Licence conditions.

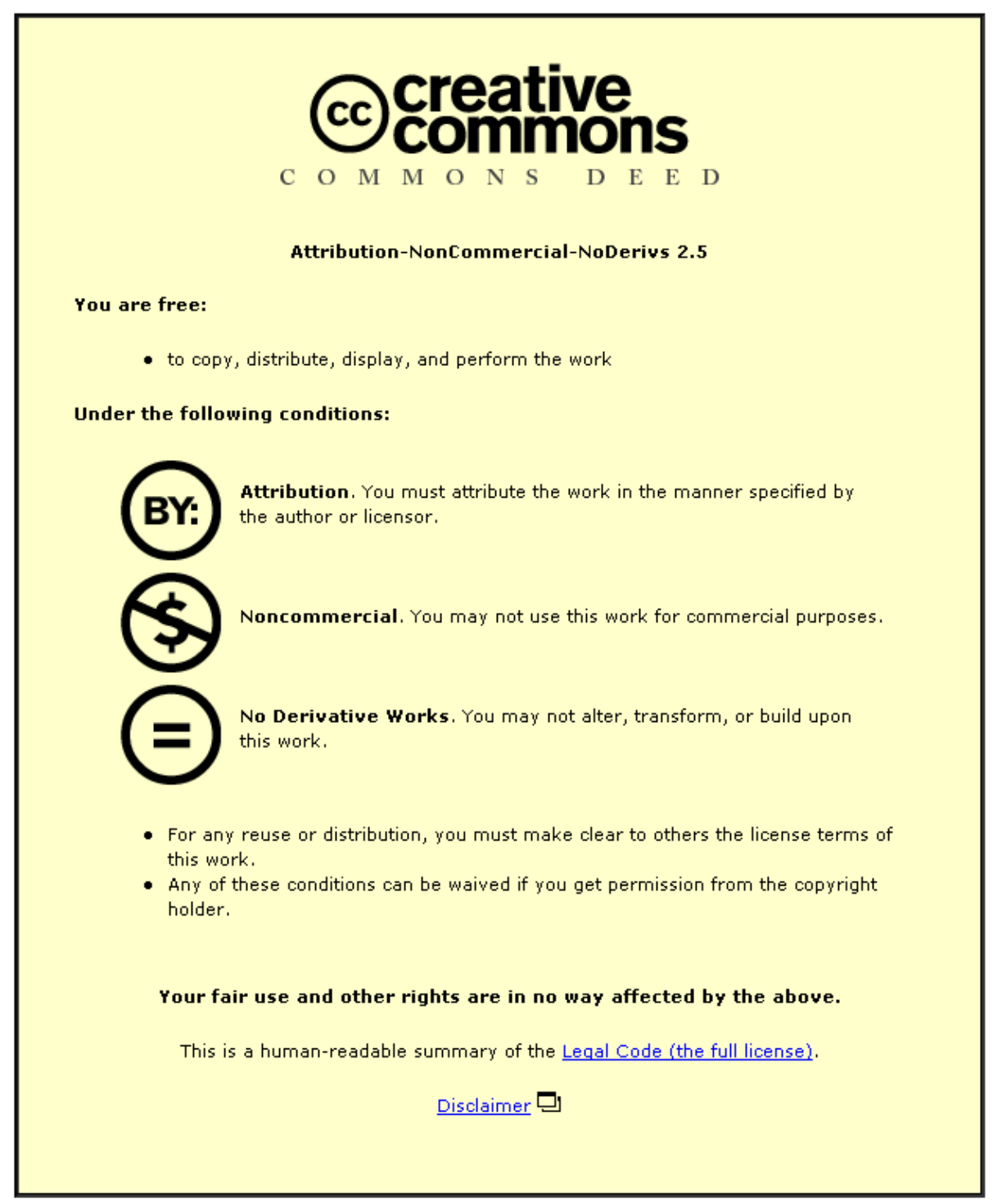

For the full text of this licence, please go to: http://creativecommons.org/licenses/by-nc-nd/2.5/ 


\title{
Implementing environmental improvements in a manufacturing context: a structured approach for the precast concrete industry
}

\author{
Hafiz Elhag, \\ Department of Civil and Building Engineering, Loughborough University, Loughborough, \\ United Kingdom, LE11 3TU. \\ E-mail: H.K.Elhag@lboro.ac.uk, HKE@britishprecast.org, Fax: 01162514568
}

\section{Jacqueline Glass}

Department of Civil and Building Engineering, Loughborough University, Loughborough, United Kingdom, LE11 3TU.

E-mail: J.Glass@lboro.ac.uk, tel. 01509 228738; fax. 01509223945.

\author{
Alistair G. F. Gibb \\ Department of Civil and Building Engineering, Loughborough University, Loughborough, UK, \\ LE11 3TU. \\ E-mail: A.G.Gibb@lboro.ac.uk, tel. 01509 223097; fax. 01509223945. \\ Martin Clarke \\ British Precast Concrete Federation (BPCF), 60 Charles Street, Leicester, UK, LE1 3GR. \\ E-mail: MAC@britishprecast.org, Fax: 01162514568.
}

\section{Clive Budge}

British Precast Concrete Federation (BPCF), 60 Charles Street, Leicester, UK, LE1 3GR.

E-mail: CJB@britishprecast.org, Fax: 01162514568

\section{Geoffrey K Bailey}

Tarmac Topfloor Limited, Weston Underwood, Ashbourne, Derbyshire, UK, DE6 4PH.

E-mail: Geoff.Bailey@Tarmac.co.uk, Tel : 01332 868400, Fax: 01332868511

Elhag, H., Glass, J., Gibb, A.G.F., Clarke, M.A., Budge, C. and Bailey, G., "Implementing environmental improvements in a manufacturing context: a structured approach for the precast concrete industry", International Journal of Environmental Technology \& Management, 8(4), 2008, pp 369 - 384, ISSN: 14662132. 


\title{
Implementing environmental improvements in a manufacturing context: a structured approach for the precast concrete industry
}

\author{
Elhag, H., Glass, J., Gibb, A.G.F., Clarke, M.A., Budge, C. and Bailey, G
}

\begin{abstract}
In common with other industries, most of the measures and solutions employed by companies in the $£ 2$ billion UK precast concrete manufacturing sector are linked to profitability. The concept of sustainability adds new dimensions as social progress and environmental protection become end goals in themselves, rather than objectives to achieve economic growth. This paper explores the nature of the precast industry and discusses opportunities and challenges relating to environmental improvement. A holistic view of the manufacture and procurement of precast concrete products is used to offer environmental improvement criteria an enhanced status in relation to the profitability imperative.
\end{abstract}

Keywords: precast concrete; sustainable development; business drivers; cement content; energy consumption; waste generation.

\section{INTRODUCTION}

The manufacture of precast concrete products is a $£ 2$ bn sector within the UK construction industry that employs 22,000 people and accounts for nearly $28 \%$ of the total cement and concrete market (Smith et al, 2002). The main manufacturing activities involved include raw material mixing, product casting in moulds (or on long casting beds), product curing (using heat and/ or steam), storage, product transport and, finally, assembly at a construction site. Typical products include precast blocks, pavers, lintels, tunnel linings, culverts and other structural elements; precast concrete products are used widely in buildings and infrastructure projects.

As with any other business all procedures, measures and communication channels are built around the concept of maximum (short and/or long-term) profitability. For conventional precast concrete production this means products should be designed to be manufactured to maximum quality, least cost, and within the shortest lead times.

The concept of sustainable development (DETR, 2000; and subsequently, HM Government, 2005) adds a new dimension to the precast manufacturing scenario as social progress and 
environmental protection become end goals in themselves rather than simple objectives to achieve economic growth. This will have considerable impact on precast companies because conventional technical or managerial solutions (such as increased cement content) could conflict with sustainability objectives. A range of technical/ managerial solutions with potential long-term or short-term sustainability advantages can be identified: these scenarios are the subject of this research - a business-focused approach to implementing sustainability improvements.

This demonstration paper is part of a research project which aims to explore the impact of sustainable development and environmental protection measures on the business case of precast concrete production systems. In this case, precast concrete hollowcore floors and beams. As noted above, profitability is achieved through manipulating specific business drivers or measures, such as functionality, delivery times, costs, overheads, and quality. These in turn are improved through specific economic and managerial solutions employed in different strategic, technical and operational levels in a precast concrete organisation. However, as well as affecting the 'bottom line' [1], such solutions also have a range of different environmental impacts (e.g. via $\mathrm{CO}_{2}$ and $\mathrm{SO}_{2}$ emissions, energy consumption, physical waste, etc.).

By understanding and quantifying the direct and indirect links between business drivers and environmental impacts, and placing these cause-and-effect relationships in a more holistic, process-based and understandable context, it should be much easier for precast concrete manufacturers to understand the impact of decisions and implement sustainability improvements without compromising the business case for precast products.

\section{BUSINESS DRIVERS FOR PRECAST MANUFACTURERS}

The efficiency of any production system (or business entity) is measured by profits; the lifeblood of any corporation and its means of growth (Smart, 1992). Precast manufacturing is no exception to this. Sources from the literature give a clear view of the business drivers and objectives that precast manufacturers pursue in order to achieve business improvement. For example, Levitt (1982) summarises the precast manufacturer's workability business case interests in five points:

- Does the addition/ change improve the early (0-10 minute old) handling properties?

- Does the addition/ change improve early (6-18 hours old) strength?

- Does the product have a better surface appearance, sharp edges, and corners? 
- How are other relevant properties (including thermal and sound insulation, and other properties associated with design and fixing details) affected?

- Does one get less wear and tear on machinery and plant?

All the points mentioned above are aimed at time, quality (appearance), functionality (structural strength), and cost/ overheads (maintenance). The same drivers are also addressed by Richardson (1991) who stresses that capital cost, unit cost of concrete produced, ease of application in the working environment and controllability must be the main criteria against which any system is evaluated.

The need to achieve these key business drivers (functionality, quality, reduced costs, shortened lead times) entirely shapes the various economic, technical, and managerial solutions employed by manufacturers. The fact that some of these solutions (such as increasing cement content, accelerated curing, Just-In-Time deliveries, etc.) could have a negative or positive environmental impact is typically not considered to be part of the business case for current precast concrete production systems. The growing importance of the sustainability agenda within UK and European legislation means that this omission is significant now and likely to continue to be a critical issue for the precast industry in the future.

\section{MAJOR ENVIRONMENTAL IMPACTS FROM PRECAST CONCRETE PRODUCTION}

The manufacture of concrete products is associated with a range of environmental impacts. These usually differ in occurrence and level of effect; Figure 1 gives an indication of the typical environmental impacts for concrete production.

In precast manufacturing a number of specific issues emerge. Bijen (2002) stresses that the main environmental burdens in precast manufacturing are associated with cement content and transportation. The energy-intensive process of cement manufacture accounts for nearly $65 \%$ of total $\mathrm{CO}_{2}$ emissions and $46 \%$ of the embodied energy content of precast hollow-core products (Addtek, 2000). Transportation impacts for precast products can also be significant because of the weight and size of units. In addition, considering the economic aspects of production, two more environmental impacts need to be considered. These are the relationship of (a) Energy Consumption; and, (b) Waste Generation, to associated economic penalties (i.e. The Climate Change Levy [2] and the Aggregate Levy [3] respectively). These key issues will be considered in depth in the research; outline information is presented below. 


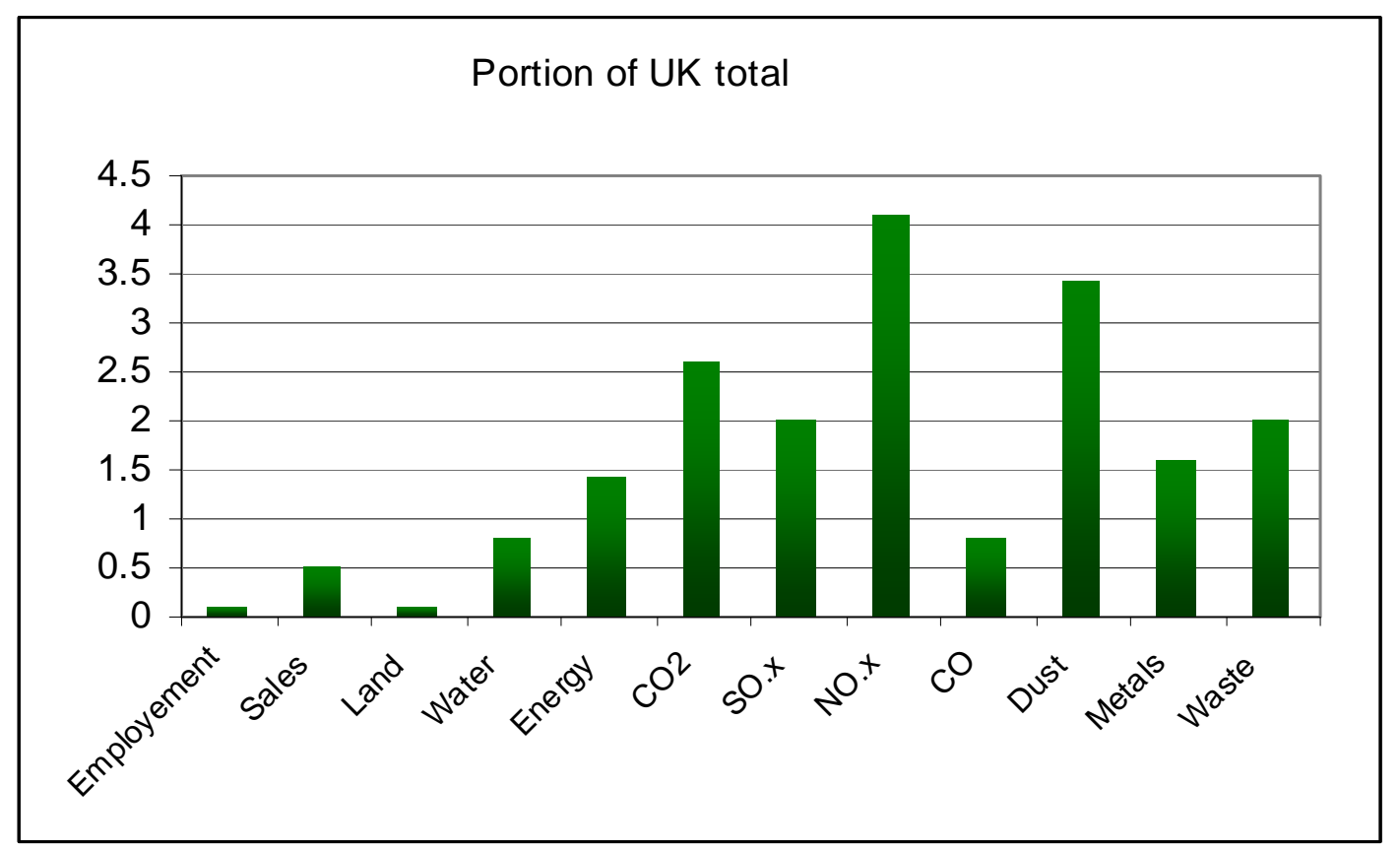

Figure 1. The contribution of concrete production as a percentage of the UK total economy, consumption and emissions (including all industry and community sectors) (Concrete Society, 2001).

\section{Cement content}

Most of the environmental impacts in a precast product's life-cycle come from raw materials extraction, transport or manufacture (Vares and Hakkinen, 1999). Although the amount of cement present in concrete may be less than $15-20 \%$ of the mix, cement remains the major raw material contributing to emissions from concrete production. Table 1 shows the various environmental impacts associated with the production and transport of the ingredients of precast hollowcore units. The table clearly shows the substantial contribution of cement to the products' environmental impact. This broadly explains how a slight change to the cement content (i.e. changing the figures along the weight row) can have a significant impact on $\mathrm{CO}_{2}, \mathrm{SO}_{2}, \mathrm{NO}_{\mathrm{x}}$ emissions, and energy consumption levels associated with concrete. For example, cement commonly represents just $13 \%$ of a precast unit by weight, but accounts for most of the four impact categories shown. A small change in cement content can significantly affect the overall environmental impact of a product, but the lion's share of environmental impacts associated with one tonne of product will still arise from cement. 


\begin{tabular}{|l|l|l|l|l|l|}
\hline & Steel & Cement & Aggregates & Admixtures & Water \\
\hline Weight & $1.4 \%$ & $13 \%$ & $80 \%$ & $0.1 \%$ & $5.5 \%$ \\
\hline \multicolumn{5}{|l|}{ Environmental Impacts } \\
\hline $\mathrm{CO}_{2}$ & $18.5 \%$ & $77.5 \%$ & $1.7 \%$ & $2.3 \%$ & - \\
\hline $\mathrm{NOx}$ & $25.2 \%$ & $60.2 \%$ & $10.1 \%$ & $4.5 \%$ & - \\
\hline SO $_{2}$ & $13.9 \%$ & $81.8 \%$ & $2.1 \%$ & $2.2 \%$ & - \\
\hline Energy & $26.1 \%$ & $67.9 \%$ & $4.2 \%$ & $1.8 \%$ & - \\
\hline
\end{tabular}

Table 1. Hollow-core flooring: relationships between individual raw materials (by \% of weight) and their \% contribution to the product's environmental impact (cradle-to-gate) (Addtek, 2000).

Several business factors influence the amount of cement used in precast concrete mixes, these include:

- Functionality: cement is a main contributor to the strength and performance of precast concrete elements; increasing cement content will, within limits, improve strength and durability.

- Time: some precast manufacturers increase cement content in concrete mixes to achieve higher levels of structural and handling strength at earlier ages (Levitt, 1982; Taylor, 1992; Richardson, 1992). Using dry or semi-dry casting techniques, the water/ cement ratio is about $0.35-0.5$ in precast extruded elements and can range between $0.2-$ 0.3 for some ultra-high strength concrete products (Schmidt et al, 2003).

- Quality/appearance: the amount of cement used has an impact on appearance, for example, Taylor (1992) states how cement content improves acid resistance qualities which increase durability and help maintain the desired appearance.

- Cost: the amount of cement used is also governed by cost requirements; cement is usually the most expensive raw material used in precast production. Most cement reduction techniques employed by precast manufacturers are driven by an economic argument.

Solutions to address most of these environmental problems include the use of alternatives, usually by-products from other industries, such as Pulverised Fuel Ash (PFA) [4], Ground Granulated Blast-furnace Slag (GGBS) [5] and other secondary and recycled material. In 
some cases combinations of these with or without limestone fillers are used. Two examples of key operational and business-case issues with these alternatives are given below.

- Some secondary products can affect the early strength properties of concrete and therefore set limitations to a precast element's use (Toutanji et al, 2004). However, strength properties can increase in later ages surpassing that of traditional concrete.

- PFA in large quantities can retard the curing process (Li \& Zhao, 2003). Due to the importance of fast concrete curing to the precast business (this enables faster demoulding and thus faster availability of the product), such an impact can have a severe effect on a precast manufacturer's business case.

\section{Transportation}

There are several transportation stages involved with the manufacture of precast products, both for the raw materials and for the finished product. At least theoretically, the proportion of impacts given over to transport of precast products might seem to be more substantial than that for other building products due to the weight of products, but in practice this would depend on products manufactured loading/ efficiency and nature of the supply chains.

Transport affects six of the thirteen impact categories usually considered in Life-Cycle Assessments; these include Climate Change, Acid Deposition, Human Toxicity emissions, Eutrophication (depletion of dissolved oxygen) and Fossil Fuel Depletion. Alexander et al (2003) argue that precast product transport holds some environmental advantages; the repetitive routes and standardised operations for precast products and raw material transport are simpler to tackle and improve. Moreover, environmental impacts arising from recurring trips to and from site for formwork, propping, scaffolding, etc. are avoided. Nevertheless, transport contributes a relatively small amount of a precast product's total environmental impact compared with cement content. Table 2 is adapted from a Finnish study of hollowcore products (Vares and Hakkinen, 1999), it shows the minor contribution of Transportation within the total cradle-to-site impacts (from extraction of raw materials to delivery to construction site). 


\begin{tabular}{|l|l|l|l|l|}
\hline & $\mathrm{CO}_{2}$ & NOx & $\begin{array}{l}\text { Heavy metals } \\
\text { emissions }\end{array}$ & $\begin{array}{l}\text { Fossil Fuel } \\
\text { Depletion }\end{array}$ \\
\hline $\begin{array}{l}\text { Raw material } \\
\text { transportation }\end{array}$ & $3 \%$ & $8 \%$ & $<1 \%$ & $4 \%$ \\
\hline $\begin{array}{l}\text { Product } \\
\text { transportation }\end{array}$ & $5 \%$ & $14 \%$ & $<1 \%$ & $6 \%$ \\
\hline
\end{tabular}

Table. 2 Hollowcore flooring: the relative contributions of transportation impacts (cradle-to-site) (Vares \& Hakkinen, 1999).

Several business measures influence transportation impacts, including:

- Economic strategic measures: precast concrete manufacturers make major strategic decisions, on location, type of product manufactured, territorial extent of activities, or supply chain partners. These decisions have a direct impact on all aspects associated with environmental impact from transport (mainly logistics, transport routes, packing and handling, etc.).

- Cost-based operational measures: for example a decision to use third party distribution or other more flexible transport measures based on lean thinking principles [6] would affect volumes and quantities of deliveries. This would affect transport environmental impacts. Similarly, a decision to simply outsource or share truck journeys would also affect the environmental impact of transportation (according to the level of coordination between the precast manufacturer and transport sub-contractor).

- Time-based operational measures: with new forms of procurement requiring more prompt and Just-In-Time (JIT) deliveries, time management plays a major role in shaping transport modes, quantities, and frequency of deliveries. The Working Time Directive [7] is another piece of legislation that can oblige manufacturers to reconsider transportation/distribution and thus influence environmental impacts.

- Quality-based operational measures: the measures required to transport and handle custom made large-scale volumetric elements are less efficient per cubic metre of product delivered to those required for relatively smaller standardised precast components (sleepers, roofing tiles, etc.).

\section{Energy consumption}

The impact of energy consumption is associated with fossil fuel depletion and greenhouse gas emissions. Precast concrete manufacturing is not as energy intensive as cement or steel 
production. The average energy consumption in precast plants is $790 \mathrm{MJ} / \mathrm{m}^{3}$ (Asumnaa, 1999). Although there is a lack of literature in this area, there are several reports confirming that precast concrete energy performance is better than that of in-situ (cast-in-place) concrete (e.g. Alexander et al, 2003). Table 3 shows that the reduced weight/volume of precast hollowcore per unit area plays a major role in reducing energy consumed, mainly by consuming less material in its production. The amount of $\mathrm{CO}_{2}$ emissions from precast concrete factories is estimated to be between $8 \%$ (Vares and Hakkinen, 1998) to 10.6\% (Alexander et al, 2003) of total cradle-to-site $\mathrm{CO}_{2}$ emissions associated with a precast product.

\begin{tabular}{|c|c|c|c|c|}
\hline \multirow{2}{*}{$\begin{array}{l}\text { Item } \\
\text { Cement }\end{array}$} & \multicolumn{2}{|c|}{ Hollowcore slab $\left(\mathrm{MJ} / \mathrm{m}^{2}\right)$} & \multicolumn{2}{|c|}{$\begin{array}{l}\text { in-situ (Cast-in-place) } \\
\text { slab }\left(\mathrm{MJ} / \mathrm{m}^{2}\right)\end{array}$} \\
\hline & 186 & $(46.3 \%)$ & 389 & $(71.2 \%)$ \\
\hline Steel & 45 & $(11.1 \%)$ & 60 & $(11 \%)$ \\
\hline Other raw materials & 15 & $(3.7 \%)$ & 23 & $(4.2 \%)$ \\
\hline $\begin{array}{l}\text { Manufacturing } \\
\text { process }\end{array}$ & 128 & (31.9) & 32 & $(5.9 \%)$ \\
\hline Transportation & 28 & $(7 \%)$ & 42 & $(7.7 \%)$ \\
\hline Total & \multicolumn{2}{|c|}{$401 \mathrm{MJ}$} & \multicolumn{2}{|c|}{$560 \mathrm{MJ}$} \\
\hline
\end{tabular}

Table 3. Energy consumption comparison for common concrete flooring solutions; precast hollowcore and in-situ construction (Alexander et al, 2003).

Business measures that can influence energy consumption include quality-based changes to mix content such as changes in cement or accelerator content affecting curing energy levels, time-based changes such as accelerated curing and cost-based improvements (e.g. using long casting/ curing beds or large handling and containment systems to run plants at maximum capacity, lowering energy consumption in factories by $25 \%$ (Asumnaa and Anttoni, 1999)). Accelerated curing helps manufacturers achieve $70-80 \%$ of the 28 day strength of a precast product in just 8-16 hours (Ball, 2002), but most energy consumed in precast plants is caused by such heating and accelerated curing. The introduction of mechanised systems (such as pallet systems) has been shown to reduce energy consumption. Moreover, strategic economic measures such as selecting the size of production facilities are also factors which will have an influence on the environmental impact (Kaysser and Kott, 2002), see Figure 2. 


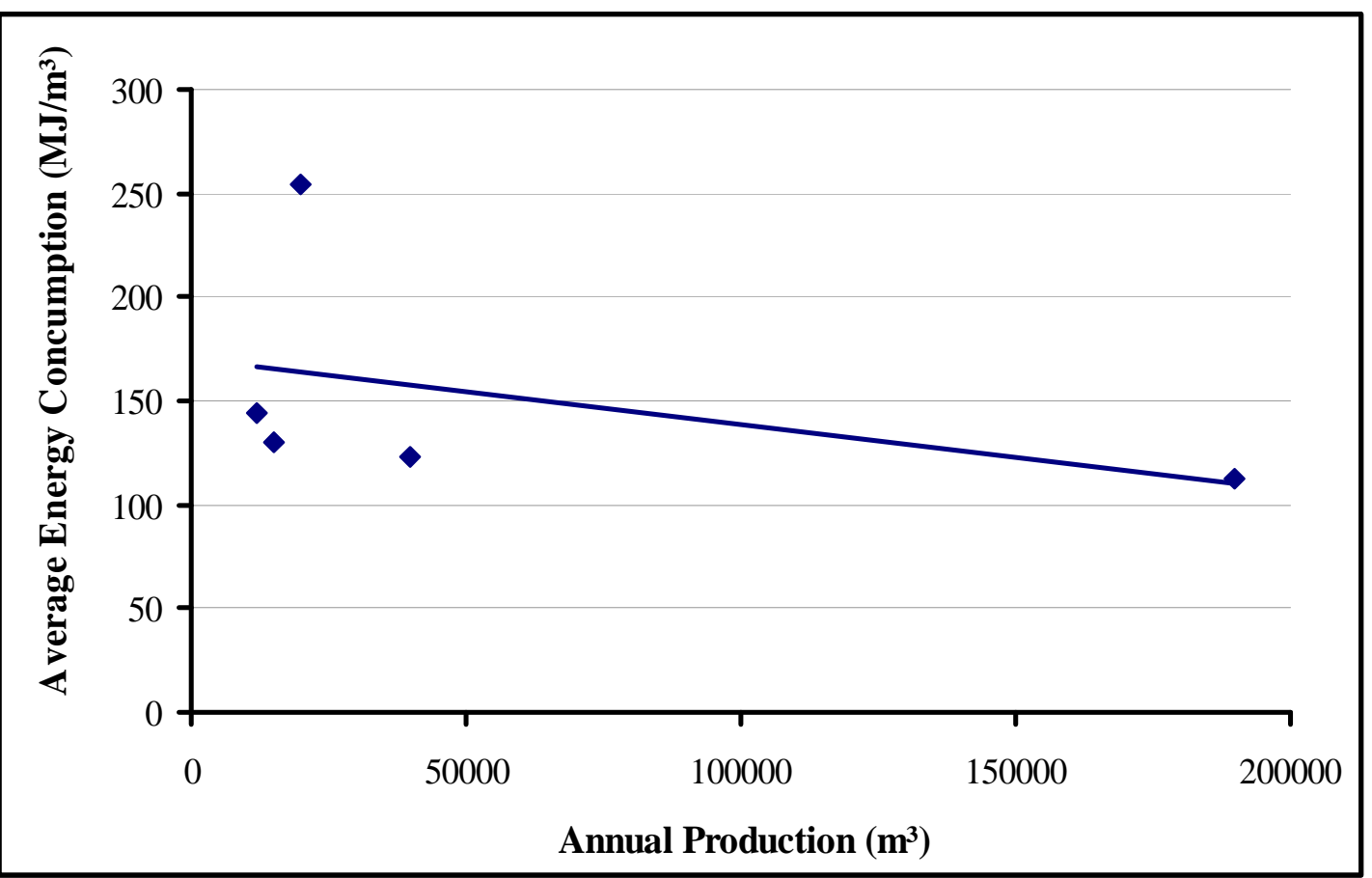

Figure 2. Impact of production volume at precast factories' (in $\mathrm{m}^{3}$ ) on energy consumption levels - Data taken from five different precast factories with different annual production capacities (Kaysser \& Kott, 2002)

The use of renewable energy in precast plants is not a widespread practice, but there is evidence of use of bio-mass for limited managerial or shop-floor activities (Trent Concrete, 2004). However, it should be remembered that these alternatives need to meet economic and social targets as well as environmental enhancement. The employment of more economically and environmentally efficient new production principles, such as Factor Four [8], might have an even greater effect on energy consumption (Weizacker et al, 1998).

\section{Waste generation}

The UK construction industry produces vast quantities of waste. In 1999, it was estimated that 72.5 million tonnes of construction and demolition waste, including clay and subsoil, were produced annually (Symonds Group, 2001). This represents some 17.5\% of the total waste produced in the UK. There are several streams of concrete waste in a precast factory, depending on products being manufactured. In hollowcore production, most concrete waste arises from cutting and removal of concrete portions to provide testing cubes, openings or to achieve specific bespoke designs, waste also comes from discarded elements due to breakdowns, casting, setting-out or curing defects, and concrete slurry and sludge due to spillage. 
The amount of concrete waste generated in typical precast plants does not appear to be significant; anecdotal accounts suggest $<5 \%$ of gross production would be typical. Figures from the PRODOMO study estimate hardened concrete wastes to be around 1-3\% of gross production (Kaysser and Kott, 2002). However, this percentage will probably increase if all concrete waste strands, including bespoke design waste, were to be considered. Figures from a Dutch study reveal that cradle-to-site solid wastes might reach $13.6 \%$ of the total net mass of a hollowcore product where this includes all concrete/ non-concrete general waste including waste from raw materials extraction, general rubbish and packaging in factories and construction sites (Fluitman and De Lange, 1996).

Waste generation in precast production and installation is less than that for in-situ concrete, this is due to the higher levels of process control at factories compared to site based operations. Furthermore, there is better continuity of work (using same type of concrete) so there are fewer 'ends of runs of production' to cause waste and less abortive work due to mistakes, failure of formwork, etc., as frequently occur on site. As known, precast assembly and erection at site produces minimal amounts of waste; two surveys, both carried out in Western Europe in 1996, estimate waste from precast structures building sites to be more than one third (35 and 38.2\%) less than in-situ concrete structures sites (Alexander et al, 2003; Fluitman and De Lange, 1996).

Business measures affecting precast concrete waste generation are varied. Collective experience from several decades of manufacturing enables manufacturers to make appropriate decisions on concrete mixes and maintenance scheduling including what aggregates and cement to use if a good surface finish is required, what time and under what conditions to mix concrete on a cold winter or warm summer day, how to achieve early age strengths for handling and packaging, and tackling aggregate moisture level problems varying throughout the year. These decisions tend to be based on conventional, common place understanding and take place without necessarily referring to quality manuals. These, and other quality control and inventory measures, determine levels of concrete waste.

The most common measure to tackle, or compensate for, impacts of waste is through recycling/reuse of the concrete waste. New government measures initiated to minimise concrete waste, such as the Aggregates Levy, Landfill Tax [9], and newly adopted European Standards, have encouraged and in some cases mandated that precast manufacturers revisit concrete waste issues. Under these conditions, it is fast becoming economic to recycle concrete waste, carried out through crushing the waste and reusing it as aggregate. 
However, using recycled concrete in precast production may still have some drawbacks such as loss of compressive strength, high variability in mechanical behaviour (Tam et al, 2005), requirement for extra cement (Bijen, 2002), or additional managerial and financial implications from handling additional ingredient(s). Results from a number of recent studies show that many of these problems can be tackled successfully, with some suggesting an overall strength gain from using recycled aggregate.

The environmental impacts described above are influenced by the specific technical and managerial solutions used by precast concrete manufacturers to achieve business drivers. Managerial/ technical solutions contribute, directly or indirectly, to a positive or negative environmental impact. Clearly the effective, rational manipulation of major contributory factors such as the cement content in precast products, techniques for accelerated curing and arrangements for transportation of the final product could have major sustainability benefits. However as stated previously the complexity of the problem and the fact that some drivers are more influential than others makes this evaluation difficult. A simple, yet holistic methodology is required to undertake this analysis and provide practical advice via scenarios whereby manufacturers can weigh up the pros and cons, and choose to trade-off where appropriate.

\section{DEVELOPING A HOLISTIC APPROACH}

Different economic and environmental characteristics affect one another on a daily basis in a precast production operation. Overlooking this could lead to a failure to understand and appreciate the environmental, social, and economic consequences of decision making in a precast concrete organisation. An approach to this problem is being devised to provide a sound basis for manufacturers' decisions, based on tracking the decisions and measuring their influences both environmentally and economically; in so doing, the approach should:

1. Recognise the specific economic/managerial solution(s) and characteristics associated with a specific decision. Any decision undertaken on materials, machinery or operational systems will have an influence on the solutions adopted; recognition is essential to understanding the full effect of the decision.

2. Recognise interaction between different solutions. There will be knock-on effects from any change; brainstorming could be used to identify potential effects.

3. Quantify environmental and economic impacts: based on available information (previous LCA studies for the plant prior to the change) and secondary information from other studies where similar solutions were used. The most important 
environmental criteria are upstream impacts (cement content), energy consumed, transportation impacts, and concrete waste generated.

4. Adopt a scenario-based method: to show and demonstrate the sequence of changes taking place due to a specific decision. Many tools help in constructing such scenarios; these include cause-and-effect techniques, Five Whys approach, and simple brainstormed process trees.

To demonstrate what is meant by such a scenario, the use of limestone aggregate can be taken as an example (see Figure 3).

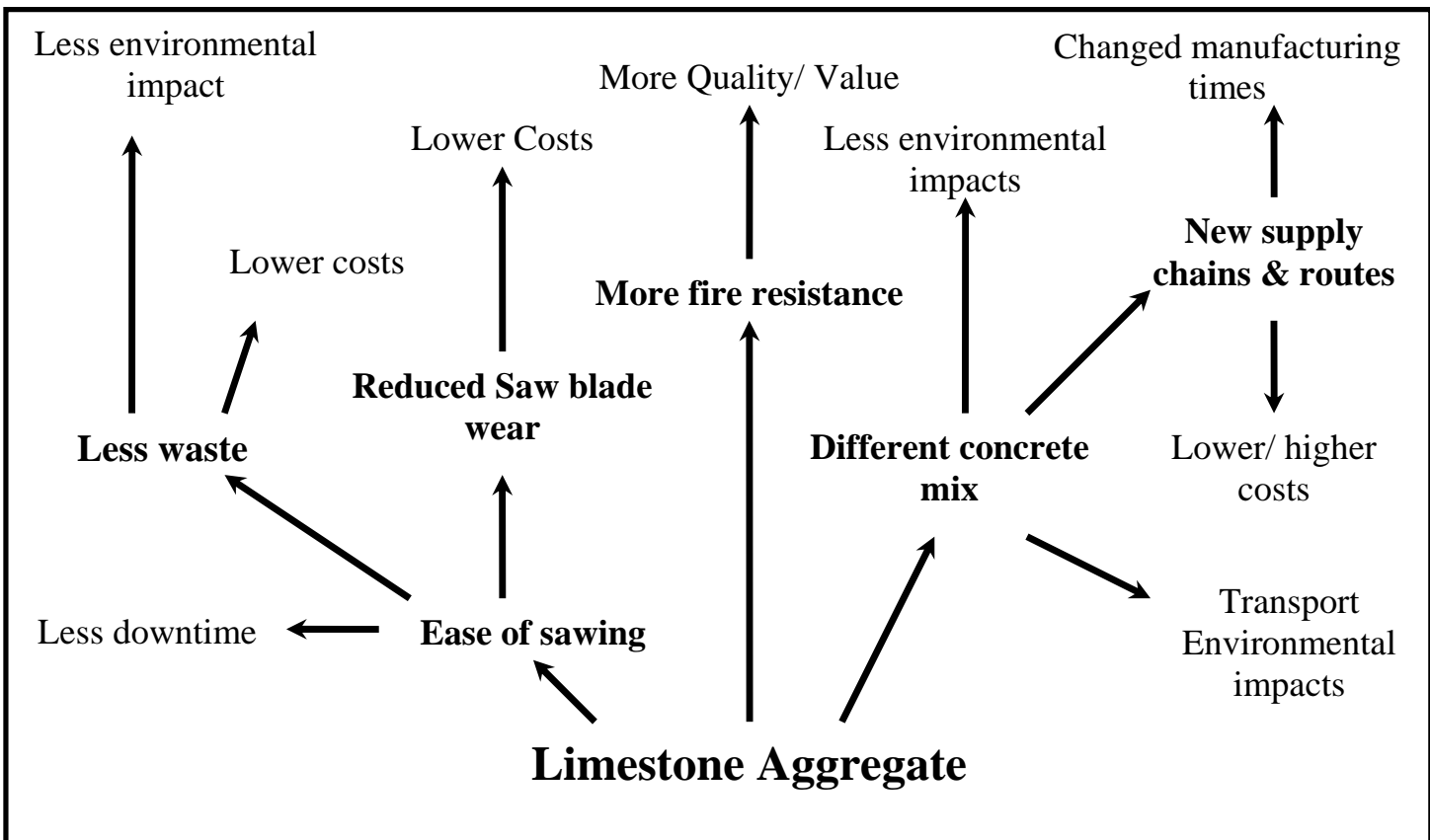

Figure 3. Scenario exploration: a process tree showing possible implications of using limestone as coarse aggregate in precast concrete hollowcore production.

Limestone can be used by precast manufacturers in several forms; this example is based on the use of dolomitic limestone as coarse aggregate in precast hollowcore production. Manufacturers usually use 10-14 mm stone in hollowcore. Manufacturers may have only a single type of aggregate economically available at their manufacturing site, but in some areas there may be a number of different types of aggregate available. The choice may be between gravels (largely made of quartz, flint or other very hard and abrasive material) and limestone. Limestone with $\mathrm{CaMg}\left(\mathrm{CO}_{3}\right)_{2}$ (mineral dolomite) content is chosen as aggregate to minimise the costs of sawing (Richardson, 1991). The sawing process itself becomes easier and quicker and there is less idle time replacing worn saws, time consumed on precast 
products damaged during rough sawing, etc.). However, looking at the bigger picture, improvement of the sawing process has other implications; the number of damaged precast elements could decrease and, therefore, costs and environmental impacts (energy consumption, associated gaseous emissions, and waste transport impact) will decrease accordingly.

However, the use of limestone aggregate requires a particular concrete mix, disrupting logistical and supply chain arrangements for manufacturers. Richardson (1991) notes that the mix for pre-stressed flooring elements can change slightly when limestone aggregate is used. The cement content can drop by $1.5-2 \%$ which reduces emissions considerably by approximately $17.6 \mathrm{~kg}$ of $\mathrm{CO}_{2}$ per one tonne of production. This change impacts on the supply chain, which again will cause a change in environmental impacts (coming from upstream operations) and transport impacts considering that limestone with mineral dolomite content is mainly extracted in the Eastern parts of England (National Statistics, 2003). This causes a difference in impacts depending on location, many manufacturers are able to achieve this through employing cheaper (and more sustainable) means of transport such as trains. A final economic/ business orientated advantage is the ability of limestone aggregates to offer better performance in terms of fire resistance (BIBM, 2003). This can increase the quality of the precast element and accordingly increase market prospects and profits in the long term. However, its impact on price or instant profits is still under question. This example shows a typical set of characteristics and options/ solutions, etc. and could be expanded further to include other issues such as the impact of the curing process and predicted impact on delivery times and organisation of handling and internal transport systems. In any case, it shows how a holistic and systematic scenario-based approach can be used to understand and view the different gains and impacts in a typical precast production situation.

A number of other scenarios could be formulated and explored, such as:

- Reducing the amount of heating used for curing to reduce energy and utilities bills, with the knock-on effect that the time required for curing will have to be increased, cement content might need to be increased, or alternative handling methods might need to be developed to move products containing less 'mature' concrete from the casting bed.

- Reducing waste streams such as by introducing recycling, water recovery, using or trading waste materials with other industries, or by marketing staff working with clients to promote ways of minimising factory waste caused by designers' decisions.

The approach will be developed further to incorporate process maps, information on technical/managerial solutions, human factors behind production decisions and the various 
impacts of those decisions. Quantitative and qualitative information collection and analysis tools will be used including LCA, process mapping interviews, questionnaires, factory surveys and brainstorming techniques etc., as described below.

\section{Data Collection and Analysis}

Precast concrete manufacturers produce a wide range of different components and elements varying in terms of volume, shape and structural ability; each of these usually go through a range of manufacturing processes employing different equipment and production measures. This research is concentrating on pre-stressed flooring elements (in particular, hollow-core slabs and pre-stressed beams). These products are a significant market for the precast industry and offer sufficient scope and breadth for research.

Qualitative and quantitative data need to be considered. A Life-Cycle Assessment (LCA) Methodology is used to identify the environmental impacts occurring during production. Detailed surveys of waste quantities and sources, energy consumption patterns, and concrete mix implications will also be carried out. The findings from the LCA will be compared with existing studies (e.g. Asumnaa (1999); Vares and Hakkinen (1998), etc) and help to identify potential areas for improvement within specific factories and common issues for the whole industry. The LCA will produce a current and accurate set of environmental impact data from which scenarios can be explored authoritatively and with precision.

After assessing environmental impacts, technical/ managerial solutions used in each production stage will be identified. This will be carried out using interviews with relevant production and management staff and process mapping tools designed to collect qualitative information on the most effective solutions and elements of production and how different profitability measures (business drivers) are achieved and maintained in different production processes.

Using LCA data and secondary information from literature, the environmental contribution of each solution and measure will be identified. These will be developed as brainstormed decision-based process trees to explore if holistic scenario-based approaches can really help manufacturers make sustainable decisions without compromising the business case for precast products, thus making clear the connection between economic sustainability and environmental protection. 


\section{CONCLUSIONS}

Like other manufacturing systems, precast concrete production systems are designed to achieve organisational profitability and economic growth. These conventional production systems are, directly or indirectly, responsible for substantial environmental impacts ranging from energy consumption, to upstream impacts and emissions due to cement use, impacts and emissions associated with transportation, and concrete waste generated during production. These are usually caused by a combination of production aspects such as curing technologies used, product mix contents employed, or production principles implemented (economies of scale, lean modern principles, etc.). Strategic and operational business decisions can fail to recognise such impacts in both environmental and surprisingly, economic terms. This is due to many reasons such as the lack of a structured approach of 'accounting' for sustainability improvements, Which is caused by management inconsideration of these issues, lack of business incentives or recognition of the business incentives (such as aggregates tax, the cost of fuel, etc.) that do exist. However, high operational costs, in addition to changes to legislation on waste and resource use, are forcing the heavy materials producers to reconsider the business case as it relates to products such as precast concrete because there are now tangible fiscal penalties and/or rewards on offer.

A more holistic approach in understanding and recognising the different environmental impacts of adopted economic solutions and decisions is suggested. The approach needs to recognise the different changes occurring to the employed solutions. Using scenarios, the approach will demonstrate and quantify the environmental impacts of such changes; this will contribute to establishing a better basis for manufacturers' judgements and responses.

\section{REFERENCES}

Addtek (2000) The Addtek 2000 Environmental Report. Published by Addtek (Consolis Ltd.).

Alexander, S.; Skjelle, A.; Suikka, A.; Vamberski, J. (2003) Environmental Issues in Prefabrication ; State-of-art report prepared by Task Group 3.1, FIB; ISSN 1562-3610, ISBN 2-88394-061-4.

Asumnaa, Otto-Ville Anttoni. (1999) Optimising environmental effects of prefabricated concrete building frames. Helsinki University of Technology. (cited by Alexander et al, 2003). Ball, B. (2002) High Volume Fly Ash Concrete; Pre-cast RPT 2000 Platform Beams. ConForce Structures Ltd. November 2002. Found in the Ecosmart website: www.ecosmart.ca. 
Bijen, J.M. (2002) Environmental information on concrete; Proceedings of the International Congress on Challenges of Concrete Construction; Sustainable Concrete Construction. (Eds R K Dhir, T D Dyer and J E Halliday), University of Dundee, 5-11 September 2002; pp 57-67. BIBM (2002) An Environmental Manifesto: Precast Concrete is a natural construction product. Bureau International Du Béton Manufacture (BIBM) publishing; found in http://www.bibm.org/bibm/manifesto.pdf

Concrete Society (2001) Concrete and the environment (Fact sheet); Working Party of the Concrete Society's Materials Group, Concrete Society, Sept- 2001.

DETR (2000), Building a better quality of life; a strategy for more sustainable construction, HMSO, London, UK.

DETR (2001) Guidelines for company reporting on greenhouse gas emissions, Department of Environment, Transport and the Regions; Product code: 00-EP-1419, UK, London.

Fluitman, A; DeLange, V.P.A (1996) CREM Report no. 95.107. Comparison of the environmental effects of three storey concrete structure. Amsterdam 1996 (cited by Alexander et al, 2003).

Glavind, M.; Munch-Petersen, C. (2002) Green Concrete- A Life Cycle Approach. Sustainable concrete construction. Proceedings of the International Congress on Challenges of Concrete Construction; Sustainable Concrete Construction. (Eds R K Dhir, T D Dyer and J E Halliday), University of Dundee, 9-11 September 2002. Pp 771-786.

HM Government (2005) Securing the future: delivering UK sustainable development strategy, HMSO, London.

Kaysser, D; Kott, M. (2002) the future in view: Production-integrated environmental protection in the production of concrete and reinforced concrete components for building construction in precast plants. Betonwerk + Fertigteil + Technik, Vol.68, No.11, Aug., 2002, pp 52-57.

Levitt, M. (1982) Precast concrete: materials, manufacture, properties and usage, Applied Science publishers Ltd. Essex, England. ISBN 0-85334-994-0.

Li, G.; Zhao, X. (2003) Properties of concrete incorporating fly ash and ground granulated blast-furnace slag. Cement \& Concrete Composites, Vol. 25, 2003, pp. 293-299.

National Statistics (2003) Mineral Extraction in Great Britain: Business Monitor - PA1007, based on the Annual Minerals Raised Inquiry, (C) Crown copyright 2004. Published with the permission of Her Majesty's Stationery Office (HMSO)

Pine, J. B. (1993) Mass customization: the new frontier in business competition/ forwarded by Stan Davies. Boston, Mass; Harvard Business School Press; ISBN 0-87584-372-7.

Piscaer, B. (2003) Limestone Fillers, or Calcium Carbonate Fillers, a welcomed $\mathrm{CO}^{2}$ reducer; Proceedings of the Nordic Network Seminar on: Concrete- the sustainable construction material. Oslo; Norway- November 2003. 
Richardson, J. G. (1991) Quality in precast concrete; design- production- supervision. $1^{\text {st }}$ Ed. Longman Group UK Ltd. ISBN 0-582-05066-9.

Schmidt, M; Fehling, E; Teichmann, T; Bunje, K; Bornemann, R (2003) Ultra-high performance concrete: Perspective for the precast concrete industry. Betonwerk + Fertigteil + Technik, Vol.69, No.3, March. pp 16-29.

Smart, B (1992) Industry as a metabolic activity. Proc. National Academy of Science, Washington D.C. USA, Vol. 89, PP 804- 806, Feb. 1992.

Smith, R.A.; Kersey, J.R.; Griffiths, P.J. (2002) The construction Industry Mass Balance: resource use, wastes and emissions, Viridis Report VR4. ISSN 1478-0143.

Symonds Group Ltd. (2001) Construction and demolition waste survey: national survey of the production, recycling and disposal of construction and demolition waste in England and Wales 1999-2000, Environment Agency Technical Report P402, Environment Agency ISBN 1-85705-450-4

Tam, V. W.Y; Gao, X. F; Tam, C. M. (2005) Michrostructural analysis of recycled aggregate concrete produced from two-stage mixing approach. Cement and Concrete Research. Vol. 35, pp $1195-1203$.

Taylor, HPJ. (1992) Precast Concrete Cladding. Published by Edward Arnold: A division of Hodder \& Stoughton. ISBN 0-340-54475-9.

Toutanji, H.; Delatte, N.; Aggoun, S.; Duval, R.; Danson, A. (2004) Effect of supplementary cementitious materials on the compressive strength and durability of shortterm cured concrete. Cement and Concrete Research, Vol. 34 (2004), pp. 311 -319.

Trent Concrete (2004) Trent Concrete Ltd Website at the Worldwide web, Site link: http://www.trentconcrete.co.uk/company info/prefabrication.htm

Vares, S.; Hakkinen, T. (1998) Environmental Burden of concrete and concrete products. Technical paper from Technical Research Centre, Finland. VTT building Technology. Published by Nordic Concrete Research; Publication No.21 http://www.itn.is/ncr/publications/doc-21-10.pdf.

Weizsacker, E., V.; Lovins, L.; Lovins, A. (1998) Factor Four; Doubling Wealth. Halving Resource use. Earthscan Publications Ltd. London, UK. ISBN 0-185383-406-8. 


\section{NOTES}

[1] The "Three Bottom Lines" paradigm is a sustainable development concept suggesting that a corporation's ultimate success or health can and should be measured not just by the traditional financial bottom line, but also by its social/ethical and environmental performance. [2] The Climate Change Levy is a tax on the business use of energy with the aim of encouraging businesses to use less energy. The levy became chargeable in April 2001.

[3] The Aggregate Levy is a tax on the extraction of aggregates was introduced on $1^{\text {st }}$ April 2002. The levy (charged at $£ 1.60$ per tonne) applies to sand, gravel and rock.

[4] Pulverised Fuel Ash, also known as fly ash, is a major by-product in Thermal power plants. It is formed as a result of burning pulverised coal. The principal contents of fly ash are normally silica (30-60\%), alumina (15-30\%), iron oxide and carbon (up to $20 \%$ ), lime $(7 \%)$ and small quantities of magnesium oxide and sulphate.

[5] Ground Granulated Blast-furnace Slag is a by-product of the iron making industry, it comes from the iron blast-furnace. The slag is being quenched, by granulation, and then dried and ground to a fine powder.

[6] Lean Thinking is a highly evolved method of managing an organization to improve the productivity, efficiency and quality of its products or services. It includes a collection of successful techniques concentrating on value streaming, minimisation of waste and waiting times, and products' orders flow through the process.

[7] The Working Time Directive, approved by the European Commission, aims to ensure that workers are protected against adverse effects on their health and safety caused by working excessively long hours, having inadequate rest or disrupted work patterns. It affects (either directly or indirectly) the maximum limitations of working-hours and wages.

[8] The idea behind Factor Four is that natural resources can be used more efficiently in all domains of daily life, either by generating more products, services and quality of life from the available resources, or by using fewer resources to maintain the same standard. The principle embraces several energy and resource saving techniques and measures employed in different sectors and activities in community.

[9] The Landfill Tax was brought in by the Government on 1 October 1996, to help reduce the amount of waste landfilled in the UK and to promote the reuse and recycling of waste, and research into waste practices. The tax applies to all waste disposed of, at a licensed landfill site, unless specifically exempt. 